\title{
Dylan Thomas's The Map of Love: The Poetic Licence
}

\author{
S. Bharadwaj \\ Annamalai University, India \\ E-mail: mithrabharath@yahoo.in
}

Received: 07-01- 2015

Published: 01-09- 2015
Accepted: 19-03- 2015

doi:10.7575/aiac.ijalel.v.4n.5p.44
Advance Access Published: April 2015

URL: http://dx.doi.org/10.7575/aiac.ijalel.v.4n.5p.44

\begin{abstract}
In the early poetry, 18 Poems and 25 Poems, Dylan Thomas speaks of his awareness of the artistic heritage and also of his poetic freedom resulting in a poetic force.The Map of Love vindicates, while mapping out the continuous process of exploiting poetic licence in his works, that the poetry of the past cannot fully serve the demands of the present. Apparently, the third book offers a comparative estimate of the time-conscientious poets, Cecil Day Lewis, Stephen Spender, and Louis MacNeice and the life-conscious War poets, Roy Fuller, Alan Rook, and Keidrych Rhys.The issues involved are wider and cover the whole range of aesthetic transcendence and historic sense of Auden. Thomas, "refusing to fall in love with God ... gave himself to the love of created things ... accepting only what he could see" and created his own poetic design, "an ideal surely which ... here if anywhere is feasible." This explains why Thomas's earth-concentric poetic licence is deeper than Auden's ideology-centric poetic justice. The War poets heaved a sigh of relief as the world-concentric Thomas's 18 Poems offers a hope for poetry, "life-blood" for their poetic mind fumbling around Auden's structural consciousness. The poetic licence developed in The Map of Love is, therefore, central to an understanding of Thomas's entire poetic ouvre, more particularly, of the maturer poetry of the later phase carving out a road taken already to immortality. In the literary study of this collection, Walford Davies and John Ackerman refer to Thomas's "querying the nature" of his own "earlier adolescent attitudes." However, as their study remains limited to general or literal statements, denotative or elucidative meaning of a few individual poems, they fail to render the core of the poem, the totality of its meaning. The poetic language of this transitional poem is endowed with implications, suggestions, and modifications. Hence, this paper undertaking a comparative and contrastive evaluation of the dramatic rule and energy, the poetic licence and the poetic justice underlying the poem, strives to highlight its intrinsic values associated with contextual significances and establish Thomas's distinctive contribution to the artistic heritage of English poetry.
\end{abstract}

Keywords: poetic licence, assimilate, egotism, complexity, amplitude, erudition, and anarchy

\section{Introduction}

The Eliotian historic sense of poetry as the "wood-tongued virtue" ( Thomas, Poems 25 ), "extinction of personality" ("Tradition" 171), "objective correlative" ( "Hamlet" 100 ) provides W.H. Auden a clairvoyant insight into the past and the present, and his poems, Poems ( 1928 ) and Poems ( 1930 ) throw light on the distinctiveness of each epoch and also the continuity of movement, "that breaks one bone to light with a judgement clout," and clarifies the task of the poet to the "four crossing birds"-F.T. Prince, Roy Fuller, Alan Rook, and Keidrych Rhys — and persuades them "to service ... over the hymning heads," "bowdown the walls of the ferned and foxy woods," and "sing and swing through a brown chapel" ( Poems ) in the pre-war context. Louis MacNeice outlines the bewilderment of the War poets:

\author{
Correctly. For she stood \\ For an older England, for children toddling \\ Hand in hand while the day was bright. Let wren and robin \\ Gently with leaves cover the Babes in the Wood. (Collected Poems 200)
}

The Rilkean historic sense of poetry as "monumental ... argument of the hewn voice, gesture and psalm" ( Poems ), as an eclectic structure of subjectivity in Auden's poems written before the outbreak of the Second World War-"In Time of War" and Another Time-- explains to the dilemmatic contemporaries as well as the War poets "crumbling between the fingers, under the feet ... crumbling behind the eyes," "something twangs and breaks at the end of the street" ( $M C P$ 199 ) that even the most powerful minds are subject to the conditions imposed by historical necessity. Thomas repeats:

Storm me forever over her grave until

The stuffed lung of the fox twitch and cry Love

And the strutting fern lay seeds on the black sill. ( Poems ) 
Auden in the sonnet sequence of "In Time of War" returns to the War poets's theme of subjectivity, "the elementary rhythm of the heart" ( English Auden 155 ), but with a difference, with his "bent spirit," "a tear-tained widower grief drooped from the lashes" ( Poems ) and "blesses" the War poets, "happy their wish and mild to flower and flood" with the Rilkean subjectivity. The poet is to probe the inner mind not the trivial and ephemeral aspects of personal experience; and to explore the inner reality is to confront the void of the abyss. "While they breathed the air /All breathe took on a virtue; in our blood, / If we allow them, they can breathe again" ( $E A$ ). His concerns with subjective experience, the passive abstract mind "the intimations of mortality" are not to be confused with egotism. "And Truth a subject only bombs discuss, / Our ears unfriendly, still you speak to us, / Insisting that the inner life can pay" ( $E A$ ). An egotist imposes his own pattern on reality; but the poet's task, as Auden envisages it, is to confront the mystery and not to attempt to explain it by erecting a convenient structure of thought.

But the Apocalyptic poetry of Dylan Thomas demonstrates that these historical conditions change continually as one phase of history gives place to another, and there are corresponding changes in the realm of thought and poetry. Thomas narrates the progress of his poetic strength evolved from the poetic licence:

Morning smack of the spade that wakes up sleep,

Shakes a desolate boy who slits his throat

In the dark of the coffin and sheds dry leaves.... ( Poems )

The evolutionary progression as envisaged in Thomas's poetry is from amplitude to depth, from comparative simplicity and innocence to increasing complexity, from elementary consciousness to greater degrees of self-consciousness.

In 18 Poems, Thomas speaks of his awareness of the artistic heritage and also of his poetic freedom resulting in a poetic force:

The force that through the green fuse drives the flower

Drives my green age; that blasts the roots of trees

Is my destroyer.

And I am dumb to tell the crooked rose

My youth is bent by the same wintry fever. ( Poems 127 )

MacNeice, evaluating the endeavour of Thomas in the making of his poetic strength and vision, comments:

Vision and sinew made it of light and stone;

Nor grateful nor enchanted

Their heirs took it for granted

Having a world - a world that was all their own. ( $M C P$ )

Thomas's 25 Poems and The Map of Love vindicate that the poetry of the past, "the lean ... divinatory years," "the pale inventor's lamp," cannot fully serve the demands of the present, "the hands ... weary with sifting sands ... the burst of nuggets on the miners' camp," "the red-eyed pioneers ... facing the dark and making the desert green" $(M C P)$, and in this sense the relevance of past ideals and models is strictly limited. Thomas maps out the continuous process of exploiting the poetic licence in his works:

No silver whistles chase him down the weeks,

Dayed peaks to-day to death,

These stolen bubbles have the bites of snakes

And the undead eye-teeth,

No third eye probe into a rainbow's sex

That bridged the human halves,

All shall remain and on the graveward gulf

Shape with my fathers' thieves. (60)

The phenomenon that strikes Thomas most in contemporary culture is the shifting of interest to the inner reality of the human heart, "my heart's victim and its torturer" (Yeats 233 ), behind all encrustations. MacNeice perceives:

And ours is not. For we are unique, a conscious

Hoping and therefore despairing creature, the final

Anomaly of the world, we can learn no method

From whales or birds or worms; 
Our end is our own to be won by our own endeavour

And held on our own terms. ( 217 )

Thomas voices that the task of a poet is to render the journey of his active mind, "an old man's eagle mind," "a mind Michaelangelo knew ... that can pierce the clouds" ( Yeats 257 ); and if his rendering is to gain depth, he must undergo the whole journey himself and assimilate the universal experience into his own personal consciousness.

Thomas's self-awareness does not take away the burden of the mystery of man's life on earth; it forces him, on the other hand, to face the reality. In 18 Poems, his creative mind becomes more resolute not to flinch from the spectacle of life; it must bear the full load of the burden, experience agony and doubt, love and hate. “... a mask and a wall to shut from your spies / Of the sharp, enamelled eyes and the spectacled claws / Rape and rebellion in the nurseries of my face..." ( Poems ). His 25 Poems sharpens his perception of artistic process, his musicality and fellow-feelings, and Auden who had censured 18 Poems acknowledged Thomas as a lyric poet of sound structure and music. "Gag of dumbstruck tree to block from bare enemies / The bayonet tongue in this undefended prayerpiece...." And in The Map of Love, Thomas assimilates the "frenzy" of the War poets and "the shrouds" of Auden, "the present mouth, and the sweetly blown trumpet of lies, / Shaped in old armour and oak the countenance of a dunce..." ( Poems ), and finally achieves self-realization through W.B. Yeats's Last Poems that "summoned the generations of his house ... lay in the coffin, stopped his breath and died" ( Yeats 281 ). MacNeice brings out the relentless forwarding spirit of Thomas, the archetypal journey of his poetic mind:

$$
\begin{aligned}
& \text { I will go back where I belong } \\
& \text { With one foot first and both eyes blind, } \\
& \text { I will go back where I belong } \\
& \text { In the fore-being of mankind. ( } 202 \text { ) }
\end{aligned}
$$

Thomas's poems and prose stories in The Map of Love can be properly understood only when the readers relate his development to the appraisal and awareness of the poetic tradition in 18 Poems and 25 Poems; and it is here in the transitional volume that the conflicting loyalties and ideals of the War poets receive a sharp focus. In The Map of Love, Thomas "offers a more profound and controlled exploration of the themes that inform his earlier work. He is able to see in perspective his earlier adolescent attitudes and emotions" (Ackerman 73 ).

\section{Methods and Objectives}

In the literary study of this collection, Walford Davies and John Ackerman refer to Thomas's "querying the nature" ( 62 ) of his own early poetry. However, as their study remains limited to general or literal statements, denotative or elucidative meaning of a few individual poems, they fail to render the core of the poem, the totality of its meaning. The poetic strength of this transitional poem can be attributed to multiple implications, suggestions, and modifications resulting from the use of paradoxical language. Hence this paper, undertaking a figurative study, a comparative and contrastive evaluation of the dramatic rule and energy, the poetic licence and the poetic justice underlying the poem, strives to highlight its intrinsic values and establish Thomas's distinctive contribution to the artistic heritage of English poetry. "Syntactic and morphologic research," according to Roman Jakobson, "cannot be supplanted by a normative grammar, and likewise no manifesto, foisting a critic's own tastes and opinions on creative literature, may act as a substitute for an objective scholarly analysis of verbal art" ( 32 ).

\section{Discussion and Analysis}

Thomas had before him three norms or ideals: amplitude and largeness represented by William Wordsworth, the War poets, and Auden; the dramatic ideal represented by Yeats; and his own poetry that probed the human heart and conveyed the mystery of existence. Thomas, in the poem "I Make this in a Warring Absence," gives an exposition of the first two:

These once-blind eyes have breathed a wind of visions,

The cauldron's root through this once-rindless hand

Fumed like a tree, and tossed a burning bird;

With loud, torn tooth and tail and cobweb drum

The crumpled packs fled past this ghost in bloom,

And, mild as pardon from a cloud of pride,

The terrible world my brother bares his skin. ( Poems 70 )

His censure of the poetry of Auden and his contemporaries, the War poets and his praise of the poets, Alun Lewis and Sidney Keyes, bear the unmistakable stamp of Yeats:

And though my love pulls the pale, nippled air,

Prides of to-morrow suckling her in her eyes,

Yet this I make in a forgiving presence. ( Poems ) 
Thomas, "lured by a softening eye ... or by a touch or a sigh ... into the labyrinth of another's being" ( YCP 166 ), emulates the Yeatsian "art of minding one's own business magnanimously" and expresses cynical concern for the selfcomplacent and self-conscious War poets-- "the heroes lie ... entombed with the receipe ... of epic in their heart" (Day Lewis Collected Poems 23 ) - and persuades them to be receptive before active. His aesthetic functioning identical to Yeats's ideal of "character isolated by a deed ... to engross the present and dominate memory" ( YCP 296 ) differs from the War poets, the Lefties, and the Eliotian Auden in this. MacNeice, in his Autumn Journal, compares and contrasts:

If it is something feasible, obtainable,

Let us dream it now,

And pray for a possible land

Not of sleep-walkers, not of angry puppets,

But where both heart and brain can understand

The movement of our fellows.... ( 174 )

While harping on about the poet's affective language of sentiments, self-concerns and self-complacence, Yeats underscores the necessity of relentless probe into the burden of mystery of life, the language of magnanimity ensuring freedom and intimations of immortality:

Everything that man esteems

Endures a moment or a day.

Love's pleasure drives his love away,

The painter's brush consumes his dreams;

The herald's cry, the soldier's tread

Exhaust his glory and his might:

Whatever flames upon the night

Man's own resinous heart has fed. (YCP 181)

Man's "heart's-mysteries" ( $Y C P$ ) pave the way for magnus opus assuring "magnum annus."

The War poets, Prince, Fuller, Rook, Rhys, Lewis, and Keyes, before the outbreak of the war, were autobiographical and Wordsworthian in their juvenilia. Day Lewis records:

We are caught, all of us, in time's fine net,

Walled up in time: yet still we seek a secret

Spring, a weak mesh, where we may

Break out and be immortal. (272)

The great fault of the War poetry, says MacNeice, is what Auden and Thomas have not so understood poetry:

Where life is a choice of instruments and none

Is debarred his natural music,

Where the waters of life are free of the ice-blockade of hunger

And thought is free as the sun,

Where the altars of sheer power and mere profit

Have fallen to disuse.... $(M C P)$

Autobiographical poetry that records personal experiences and views, comparative freedom is emphatically rejected in favour of width and impersonality. What Eliot says is that "poetry is not a turning loose of emotion, but an escape from emotion; it is not the expression of personality but an escape from personality" ( "Tradition" 175 ). Auden's censure of War poetry and his praise of the older, classical poets bear the unmistakable stamp of Eliot:

And never will be perfect like the fountains;

We live in freedom by necessity,

A mountain people dwelling among mountains. (EA 262) 
Yeats defines autobiographical poetry as "irrational streams of blood ... staining the earth" ( 249 ), and MacNeice writes in a dismissive tone in Autumn Journal:

\author{
So sleep in hope of this - but only for a little; \\ Your hope must wake \\ While the choice is yours to make, \\ The mortgage not foreclosed, the offer open. (175)
}

His view of War poetry is to a great extent coloured by his dislike of the taint of egotism in the War poet's character. The choice before the War poets is between Auden and Thomas, "the past" and "the future." The "anti-heroic" poets who had not assumed "the role of prophets either" ( Shires 55 ) concentrated more on private experiences and "personal trials."

The War poets, Prince, Fuller, Rook, and Rhys realized that it was not enough for the contemporary poet to follow in the footsteps of the older master Wordsworth for their "hodded, fountain heart once fell in puddles ... round the parched worlds ... ( Poems 25 ). Thomas derides the War poets's romanticism in several of their light verses and parodies:

To take to give is all, return what is hungrily given

Puffing the pounds of manna up through the dew to heaven,

The lovely gift of the gab bangs back on a blind shaft. (Poems 105)

The War poets became increasingly serious and speculative and their mirth gradually lost its spontaneity. Day Lewis confirms their sudden shift from frustrations and doubts to desires:

Unseen the sunburst Aprils

And the bloomed Octobers-

Oh, tremulous rivers danced by primula light!

Oh, blaze of marigold where love has been! (273)

Thomas's poem "On no Work of Words" reveals the War poets's deliberate effort to relieve the inward tension.Their transition from romanticism to modernism, from Wordsworth to Auden and to Thomas, from "three lean months" to "the rich year," "the body belly" to "the big purse of my body," "no work of words" to the poet's "task" and "craft" proves, however, much too quick. Thomas comments:

To lift to leave from treasures of man is pleasing death

That will rake at last all currencies of the marked breath

And count the taken, forsaken mysteries in a bad dark. ( Poems )

The War poets's hankering for the transcendental art of moderns, their desperate effort for freedom reminds the readers of the lines from Yeats:

In pity for man's darkening thought

He walked that room and issued thence

In Galilean turbulence;

The Babylonian starlight brought

A fabulous, formless darkness in;

Odour of blood when Christ was slain

Made all platonic tolerance vain

And vain all Doric discipline. ( 181 )

The sharp tonal shifts in the War poets from the gay to the serious and from the serious to the gay indicate an effort to communicate contrary experiences, to unfold the swift movements of thought and aesthetic of Auden and Thomas. They were also reminded of the Left-lenient poets's love for Auden's musical structure and of their loss, their mixed experiences of love and fear, the non-intellective mode of perception and non-moral attitude of the ideal poetic character: here the self is conceived as barrier against sympathetic identification. "To surrender now is to pay the expensive ogre twice" ( Poems ). Prince's mind is partly abstracted and in such a state of tranced aloofness he is unable to respond fully to the reality of the situation. His experience, however, is not painful. Then, Auden's process of intensity forces upon Fuller, Rook, and Rhys the thought of death and the vehemence of pain is never experienced. Day Lewis's useful commentary shows that the War poets seek or create a relief situation: 
Tonight, as flyers stranded

On a mountain, the battery fading, we tap out

Into a snow-capped void our weakening

Vocations and desires. ( 274 )

He attributes their failure to personal comforts and concerns, their "pinprick" of "sightless hours, and pallor of weeks unquickened." There are several reasons for the abandonment of their dream-project. Distraction, anxiety, and fatigue must have contributed their share; the failure to drown the Audenesque echoes wholly may have proved another obstacle. To quote the words of MacNeice is very convincing: "Sleep to the noise of running water / To-morrow to be crossed, however deep..." $(M C P)$.

Thomas's dream-like state in 18 Poems gives way to a poignant sensation of the brevity of life and poetry. To him the richness of the artistic heritage is both an advantage and a hindrance:

One wound, one mind, spewed out the matter,

One breast gave suck the fever's issue;

From the divorcing sky I learn the double,

The two-framed globe that spun into a score;

A million minds gave suck to such a bud

As forks my eye;

Youth did condense; the tears of spring

Dissolved in summer and the hundred seasons;

One sun, one manna, warmed and fed. (58-59)

Thomas's 18 Poems demonstrates that the need to assimilate the past is as vital as to drown the echo of the predecessors and carve out an independent path. He projects Hardy's vision of poetic licence suggested in Poems for the Present and the Past and in the poem "On an Invitation to the United States" Hardy reminds:

For, wonning in these ancient lands,

Enchased and lettered as a tomb,

And scored with prints of perished hands,

And chronicled with dates of doom,

Though my own Being bear no bloom

I trace the lives such scenes enshrine,

Give past exemplars present room,

And their experience count as mine. ( 97 )

To receive the total impact of the experience one must be along with the poet the full weight of human agony, "that long drip of human tears." In 18 Poems, Thomas emulating Hardy absorbs within himself the pain and the desolation that has afflicted the human heart, "the human halves" of the poets of thirties and retains only their quintessences.

The problem of reconciling tradition with individual talent becomes increasingly more difficult with the succeeding poem, 25 Poems. He affirms:

Though they be mad and dead as nails,

Heads of the characters hammer through daisies;

Break in the sun till the sun breaks down,

And death shall have no dominion. (31)

In "Poetic Origins and Final Phases," Harold Bloom, underlining "the relation of poetic strength to poetic influence", writes that "poetic strength comes only from a triumphant wrestling with the greatest of the dead, and from an even more triumphant solipsism" ( 218 ).

In tracing the varying moments of the War poets's responsiveness to the poetic ritual of Auden and Thomas and their candour, Thomas recognizes the separateness of each mood:

After the funeral, mule praises, brays,

Windshake of sailshaped ears, muffle-toed tap 
Tap happily of one peg in the thick

Grave's foot, blinds down the lids, the teeth in black,

The spittled eyes, the salt ponds in the sleeves.... (Poems)

The contrariness is not dissolved, and the thought-process resembles a flow rather than a cluster.To reconcile the comic vision with the frightening spectre of the shrunken mood of the fellow-beings would involve the telescoping of two different perspectives. This Auden seldom achieves; what is noted chiefly is a juxtaposition of contraries. In some poems of the early poetry and in the transitional poem, however - particularly in the later phase-Thomas comes close to an inclusive vision and paradoxical structure. MacNeice felicitates the inclusive design of 18 Poems:

The first train passes and the windows groan,

Voices will hector and your voice become

A drum in tune with theirs, which all last night

Like sap that fingered through a hungry tree

Asserted our one night's identity. (109)

Auden's mockery deepens the poignancy of the situation and not just serving as a relief according to MacNeice.

MacNeice studied the poetry of the past and the work of his contemporaries and fellow-poets not with the detachment of an evaluator weighing excellences and flaws. Poetry was for him a sensation. "Fish, bird or beast was never thus unfaithful" ( $D C P 217$ ); more than any other poet of his generation he was conscious of the literary and artistic heritage, and for him awareness of this tradition meant assimilation. Thomas comments:

'If my head hurt a hair's foot

Pack back the downed bone. If the unpricked ball of my breath

Bump on a spout let the bubbles jump out.

Sooner drop with the worm of the ropes round my throat

Than bully ill love in the clouted scene. ( 78)

To respond properly to a work of art is to identify oneself completely with the author. But he went a step further; he established a parallel between his own situation and the author's, and sought for the relevance of a work of art in his own personal context.

It is true that Rex Warner's early poems provided MacNeice the closest and the most poignant parallels in the earlier phase:

\author{
Now I am left in the fire-blaze \\ The peacefulness of the fire-blaze \\ Will not erase \\ My debts to God for His mind strays \\ Over and under and all ways \\ All days and always. ( MCP 59 )
}

But MacNeice adopted a similar approach to the other poets whom he admired, and their worth was in a sense determined by the bearing of their life and work on his own situation and creative endeavour. This provides a clue to the paradox of MacNeice's admiration for and final rejection of Auden and the intervening drama projecting the inward stresses is worth a close watch.

In an early poem "Trains in the Distance," Auden is celebrated as a poet of heavenly harmony, and there is an implicit thought that to achieve Auden's poetic strength he must be matured with metaphysical philosophy. MacNeice murmurs:

But it brought us assurance and comfort all the same,

And in the early night they soothed us to sleep,

And the chain of the rolling wheels bound us in deep

Till all was broken by that menace from the sea,

The steel-bosomed siren calling bitterly. ( $M C P$ )

The poem "Glass Falling” written on Auden's Poems (1928) suggests a contrast between the genius of Warner and that of Auden. Auden's intellectual powers are pointedly emphasized in the lines: 
And soon on fleets of macintoshes

The rain is coming down, the frown

Is coming down of heaven showing

A wet night coming, the glass is going

Down, the sun is going down. ( 60 )

MacNeice renewed his study of Warner at Oxford. "And the motion is still as when one walks and the moon / Walks parallel but relations remain the same... ( $M C P$ ). The poem "Evening Indoors" indicates his divided love:

In this evening room there is no stir, no fuss;

The silken shade of the oil-light is diaphanous,

And so come other noises through the noise of the clock

Transparent as the shade, as the girl's frock.

There is no crease, no fold ruffling the room at all.

At the beginning of thirties, MacNeice's taste and his conception of poetic vocation were chiefly influenced by Eliot, "the live rafters of the eardrum." In the poem "Happy Families," MacNeice thought that Eliot seemed "to fit, excellently fit" for him. He observes:

He caught me suddenly surreptitiously

And heft me out of my shell. We'll pass that over

And forget about it and quietly sit

Knitting close, sitting close under cover. (65)

MacNeice was very happy with the musical elegance of Eliot's early poems "that rainy tongue beat back ... through the devilish years and innocent deaths ... to the room of a secret child," "her white-dressed limbs were bare," "her red lips were kissed black," "she wept in her pain and made mouths ... talked and tore though her eyes smiled" ( Poems 132 ). But he felt that the quantity of human intelligence could not be augmented to "breaking webs," comprehending Eliot. "Grope, grope, grope again / Again unseen fatalities" ( 66 ). For MacNeice, possibly the most literary of the poets of his generation, the question, as Thomas admirably points out in the poem "The Tombstone Told When She Died," took the form of a perplexing dilemma:

\author{
I died before bedtime came \\ But my womb was bellowing \\ And I felt with my bare fall \\ A blazing red harsh head tear up \\ And the dear floods of his hair. (Poems 132)
}

Thomas narrates the visuals of "the shadowplay," "death and the mad heroine" speaking "through the chipped beak ... of the stone bird guarding her." Subsequently, Eliot's role as a mentor was supplanted by Auden's and the two poetic ideals to which MacNeice veered-amplitude and dramatic objectivity, "dance on fountains and duck time" and "the shared woods with a glove on a lamp" ( Poems), were largely borrowed from Auden.

In Poems ( 1935 ), MacNeice remarked that both Eliot and Auden had already exhausted the resources and beauties of poetry, "having bitten on life like a sharp apple ... or, playing it like a fish" and "having felt with fingers that the sky is blue," and that there was nothing to talk about originality, "not the twilight of the gods," "what have we after that to look forward to?" ( $M C P$ ). The remark may have been made in a state of momentary despair, but the idea was rooted in his mind and was reinforced by the Eliotian Auden. In the essay "Tradition and the Individual Talent," Eliot, disapproving of "the tendency to insist ... upon" individuality of the poet, "the peculiar essence of the man," "something that can be isolated in order to be enjoyed," writes that "... we shall often find not only the best, but the most individual parts of his work may be those in which the dead poets, his ancestors, assert their immortality most vigorously" ( 168-69 ). Captivated by Eliot's intellectuality and complexity, "the ghost with a hammer, air,... strike light, and bloody a room" Auden implies in his post-war contemporaneous work, Poems ( 1930 ) that the idea of progress is illusory. "If my bunched, monkey coming is cruel / Rage me back to the making house" ( Poems ). He ruled out the possibility of being original, as the Apocalyptic poets claimed to be, according to MacNeice:

But, as it is, the spears each year go through

Our flesh and almost hourly

Bell or siren banishes the blue

Eyes of Love entirely. ( MCP 181 ) 
If the earlier poets had already exhausted the possibilities of imaginative expression, what was indeed left to be done by modern writers except repeating the consummate utterances of their predecessors? Was it enough for a modern writer to discern the relative excellences of the masters and emulate the qualities relevant to his own poetic purposes? And what worth such emulation would be? MacNeice asks in "Prognosis":

$$
\begin{aligned}
& \text { Will his name be Love } \\
& \text { And all his talk be crazy? } \\
& \text { Or will his name be Death } \\
& \text { And his message easy? ( } M C P 180 \text { ) }
\end{aligned}
$$

The search for a way out of the labyrinth, for a more positive approach that would direct the mind to acquire all that is essential in the past while allowing for creative experiments in keeping with the altered contemporary context, demanded a dynamic view of poetry synthesizing the influences of the public-minded Warner and of the aestheticminded Auden. The result of his aching "journey" was "a limp and rudderless shape to leap nine thinning months." Thomas recalls MacNeice's cry:

'Now to awake husked of gestures and my joy like a cave

To the anguish and carrion, to the infant forever unfree,

O my lost love bounced from a good home;

The grain that hurries this way from the rim of the grave

Has a voice and a house, and there and here you must couch and cry. (Poems)

MacNeice's distrust of Auden's dogmatic commitments precludes a neat summing up. While he was struck by the sudden insight and clarity of Thomas, he was baffled at the sametime by the convolutions in Auden's thought. He resolves:
And if the world were black or white entirely
And all the charts were plain
Instead of a mad weir of tigerish waters,
A prism of delight and pain,
We might be surer where we wished to go
Or again we might be merely
Bored but in brute reality there is no
Road that is right entirely. (MCP 181)

MacNeice's "prognosis" is based on more larger experiential truth of Thomas's early poetry rather than the axioms in the prodigies, the early poetry of the Eliotian Auden.

The poem "If My Head Hurt a Hair's Foot" reconstructs MacNeice's faith in the moral disinterestedness, the coherent musicality and cohesiveness of Thomas, "a good home":

'Rest beyond choice in the dust-appointed grain,

At the breast stored with seas. No return

Through the waves of the fat streets nor the skeleton's thin ways. (Poems)

Confirming MacNeice's "ambiguous power of choice," Day Lewis renders a sober, unprejudiced estimate of the nature of Thomas and his poetic genius comparing him with the Saviour or "Man only casts the image of his joys ... beyond his senses' reach" for redeeming the suffers of MacNeice "who weeps, a child chained to the outraged tree":

Innocent is her touch as the dawn's, but still it unleash

The ravisher shades of envy. Freedom is more than a word.

I see man's heart two-edged keen both for death and creation.

As a sculptor rejoices, stabbing and mutilating the stone

Into a shapelier life, and the two joys make one-

So man is wrought in his hour of agony and elation

To efface the flesh to reveal the crying need of his bone. (191) 
MacNeice's Poems is especially remarkable for the attempt at reexamining the meaning of tradition and formulating a new concept of movement of poetry, poetry as pure art song identical to Auden's. Day Lewis comments "that was the fatal move, the ruination ... of innocence so innocently begun..." (217).

MacNeice implied in Poems that Thomas of 18 Poems was inferior to Auden, "and be it assumed ...that no one hears them among the talk and laughter" ( $M C P 86$ ). His poem "Wolves" comments:

I do not want to be reflective any more

Envying and despising unreflective things

Finding pathos in dogs and undeveloped handwriting

And young girls doing their hair and all the castles of sand

Flushed by the children's bedtime, level with the shore. (85)

But his observations, "soundlessly collateral and incompatible," "world is suddener than we fancy it," "world is crazier and more of it than we think ... incorrigibly plural," and "the drunkenness of things being various," three months later show a groping towards a more balanced approach. His poem "Snow" underlines :

And the fire flames with a bubbling sound for the world

Is more spiteful and gay than one supposes-

On the tongue on the eyes on the ears in the palms of one's hands--

There is more than glass between the snow and the huge roses. (86)

The conclusions are of a tentative nature, and MacNeice desists from attempting systemized generalizations. Day Lewis finds in Thomas's sonnets "Altarwise by Owl-Light" an allegorical pattern that "asked of ... life no mythical splendor," "coveted never an epic part," and "hewed an everlasting ... image of freedom out of their rude and stubborn heart" which "shall flower for an age when freedom is man's creative word" ( 200 ).

Auden, MacNeice thought in Poems, was a friend to mankind; what strikes him in Poems (1930) is Auden's remoteness. In The Blind Fireworks ( 1929 ), he praises Auden as god for the sublimity and amplitude in Poems ( 1928):

Like the calm blue marriage of the sky and sea,

Or a blue-veiled Madonna beaming vacancy,

See that Madonna snuff out the shaded light

And stroke with soothing hand asleep the night. (61)

Sublimity and amplitude are no longer considered valid criteria of poetic worth; concern for humanity is now held as the standard of reference, and from this perspective Thomas appears superior to Auden. MacNeice finds:

The saint on the pillar stands,

The pillars are two,

A young man opposite

Stands in the blue,

A white Greek god,

Confident, with curled

Hair above the groin

And his eyes on the world. $(M C P)$

Thomas appears superior to Auden. To be a god is not enough; a poet must come close to the human plane. Day Lewis also compliments:

They have not known the false humility,

The shamming-dead of the senses beneath your hunter's hand,

But life's standards they've advanced

To the limit of your salt unyielding zone. (186)

The ideal of dramatic objectivity as represented by Auden in Poems also retains only a limited significance to MacNeice. In the poem "Mayfly," his remark shows the nature of his response: 
It is we who pass them, we the circus masters

Who make the mayflies dance, the lapwings lift their heads;

The show will soon shut down, its gay-rags gone,

But when this summer is over let us die together,

I want always to be near your breasts. ( $M C P 70)$

Auden appeals to him increasingly as a poet of pain, not as an empathic.Thomas repeats the harrowing experience of MacNeice's love:

I know her scrubbed and sour humble hands

Lie with religion in their cramp, her wits drilled hollow,

Her fist of a face died clenched on a round pain.... (Poems)

Auden's poems "can be no model to us; their imputed purpose / Is a foregone design... (MCP 217). MacNeice unfolds the futility of his contemporaries's "explorations":

The whale butting through scarps of moving marble,

The tapeworm probing the intestinal darkness,

The swallows drawn collectively to their magnet,

These are our protypes and yet,

Though we may envy them still, they are merely patterns

To wonder at-and forget. ( 216)

The concept of depersonalization, "the shadow and sheen of a moleskin mountain / And a litter of chronicles and bones" ( MCP 224 ), borrowed from the Eliotian Auden is ultimately rejected. MacNeice explains:

So a friend of a man comes in

And leaves a book he is lending or flowers

And goes again, alive but as good as dead,

And you are left alive, no better than dead,

And you dare not turn the leaden pages of the book or touch the

flowers, the hooded and the arrested hours. (80-81)

Thomas's archetypal "neutrality," "fermenting rivers, / And intricacies of gloom and glint" and "ducats of dream and great doubleboons of ceremony" appeals to him:

The neutral island facing the Atlantic,

The neutral island in the heart of man,

Are bitterly soft reminders of the beginnings

That ended before the end began ( MCP 224)

Day Lewis also takes "a happy view" of Thomas's poetic licence that buoys up "the sunken light" of the Lefties, that fathoms out "what rots unfathomed in the dark" in the poetry of Auden:

And if the truth were told,

You'd count it luck, perceiving in what shallow

Crevices and few crumbling grains of comfort

Man's joy will seed, his cold

And hardy fingers find an eagle's hold. (177)

Past heritage is, thus, sifted and is even modified in the process of assimilation to suit the new needs in the changed context.Thomas's poetic ideal of freedom is in contrast to Auden's historic sense and to Eliot's observation that with the introduction of a truly original work of art "the whole existing order" is "altered; and so the relations, proportions, values of each work of art toward the whole are readjusted; and this is conformity between the old and the new" ( "Tradition" 170 ). 
A close study of Day Lewis's Transitional Poem and Country Comet shows that he was fascinated as much by Warner's personality as by Auden's poetic genius. His natural modesty prevented him from drawing any explicit parallel, but the analogy was there in his mind. Warner, he felicitates later in "For Rex Warner on His Sixtieth Birthday" as "a mind of Attic dash and clarity ... Homeric simpleness, and natural charity ... for all but intellectual cliques and their baloney" ( Room 50 ). In "A Time to Dance," Day Lewis remarks that Warner lived a life of allegory, a lyrical ballad, "a theme with a happy end":

A bird's buoyancy in them, over the dark-toned earth,

To hold a sustained flight, a tune sets death to dancing;

A stormcock's song, the ecstatic poise of the natural fighter,

And a beat as of feet advancing to glory, a lilt emphatic. (DCP 142)

He found similarly an allegorical pattern in the life of Auden. He writes in Transitional Poem:

By Easedale Tarn, where I sought a comforter,

I found a gospel sterner than repentance.

Prophetic earth, you need no lumber of logic

Who point your arguments alike with a primrose

And a sick sheep coughing among the stones.... (18)

In Poems ( 1928 ), Auden censured his contemporary poet Day Lewis's preoccupation with Warner's subjectivity in Country Comet ( 1927 ) and his aspiring to the wider horizons of artistic poetry. He persuaded him to "give up his breath, his woman, his team ... no life to touch, though later there be ... big fruit, eagles above the stream" ( $E A 35$ ). He advocated the Eliotian impersonal perception of poetry: “ ... the poet cannot reach this impersonality without surrendering himself wholly to the work to be done. And he is not likely to know what is to be done unless he lives in what is not merely the present, but the present moment of the past, unless he is conscious, not of what is dead, but of what is already living" ( "Tradition" 176 ).Warner represented a way of life, and his rigorous self-discipline, struggle, and sacrifice excited the young poet's emulation in Country Comet. He admits:

That one is a constant

And suffers no eclipse,

Though I feel sun and moon burning

Together on her lips. (16)

The need for intellectual equipment and structural discipline that he felt keenly at this phase was an inner compulsion, but Auden, the scholar-artist, "my lover of air, like Artemis" who "shuns the daylight that twists her smile ... to mineral distaste ( 17 ), also provided an inspiring image:

Now summer brings what April took,

Riding with fanfares from the south,

And I should be no Solomon to look

My Shebha in the mouth. (30)

Auden's vast erudition was beyond him and he would have thought it presumptuous to suggest any comparison between Auden and himself but his plan to learn the archetypal pattern of Yeats irresistibly recalls similar statement of Auden in Poems (1930):

Orders are given to the enemy for a time

With underground proliferation of mould,

With constant whisper and the casual question,

To haunt the poisoned in his shunned house,

To destroy the efflorescence of the flesh,

The intricate play of the mind, to enforce

Conformity the orthodox bone,

With organized fear, the articulated skeleton. (65-66) 
MacNeice in the poem "Museums" endorses the views of Auden: "Makes believe it was he that was the glory that was Rome, / Soft on his cheek the nimbus of other people's martyrdom..." ( 77 ).

But Day Lewis, who had bowed down to the words of Yeats's The Tower, shaped his transitional mind and achieved his objectivity in Transitional Poem. Transitional Poem implies considerable departure from Auden and his poetic, his "musical plan" and "musical heart." In the succeeding poems, From Feathers to Iron, The Magnetic Mountain, his envy of Auden's "faultless ways" is both a defence and a repudiation of his great contemporary, Auden. Thomas recalls:

The vanishing of the musical ship-work and the chucked bells,

The wound-down cough of the blood- counting clock

Behind a face of hands,

On the angelic etna of the last whirring featherlands

Wind-heeled foot in the hole of a fireball.... (Poems 19)

The next phase of Auden's poetry of thirties — his fight for liberty and his crusade against political Communism—left an equally powerful impact on Day Lewis. He writes in Poems (1930):

Noises at dawn will bring

Freedom for some, but not this peace

No bird can contradict: passing, but is sufficient now

For something fulfilled this hour, loved or endured. (82)

The question whether and in which precise sense the poet's role in society should be functional troubled Day Lewis from almost the beginning of his poetic career, and he found an answer to this question in Auden's poems. After his lyrical poems From Feathers to Iron and The Magnetic Mountain, Day Lewis wrote an elegy in symphony in memory of his friend L.P. Hedges, and then for three years from 1933 to1936 he engaged himself chiefly in pamphleteering to serve his country and the cause of social freedom and justice; this interregnum-he wrote during this period only a handful of poems, songs, ode, lyrics, sonnet and a drama Noah and the Waters - was on Day Lewis's part a deliberate self-sacrifice. This was one way that a poet could fulfil his social obligations, by wielding his pen for extra-poetic purposes. But there was another way, perhaps a more arduous one; he could serve society by his poetry alone, and Auden exemplified this by writing Look Stranger! Day Lewis's comments in the poem “Two Songs,"

Hunger shall make thy modest zone
And cheat fond death of all but bone-
If these delights thy mind may move,
Then live with me and be my love...

show that he pondered both these directions of Auden's activity and that he had an impassioned love for the musical form of Auden. He was, moreover, an active friend to Warner, "admiring a man so able ... at undermining the crusted status quo and unchanged through time or weather" ( The Room 49 ), and "my friend who within me laughs ... bids you dance and sing” ( DCP 141 ). He sings:

$$
\begin{aligned}
& \text { Their spirits float serene } \\
& \text { above time's roughest reaches, } \\
& \text { But their seed is in us and over } \\
& \text { our lives they are evergreen. (142) }
\end{aligned}
$$

Day Lewis wrote the elegy "A Time to Dance" with much delightful prose that drove out his poetic language. "The stocked heart is forced...." Thomas comments in the poem "A Saint about to Fall":

Hymned his shrivelling flock,

On the last rick's tip by spilled wine-wells

Sang heaven hungry and the quick

Cut Christbread spitting vinegar and all

The mazes of his praise and envious tongue were worked in flames and shells. (Poems) 
Day Lewis observes in The Room and Other Poems that with this he would have been content if he could, so doing, have preserved his aesthetic functioning, "the limits of what's human," and feel of public duty performed. He remembers:

Your glancing eye, your animal tongue,

Your hands that flew to mine and clung

Like birds on bough, with innocence

Masking those young experiments

Of flesh, persuaded me that nature

Formed us each other's god and creature.

Play out then, as it should be played,

The sweet illusion that has made

An Eldorado of hair

And our love an everywhere. (11)

Day Lewis's concern "to be all in all ... each for each, a man and woman," his consciousness of comradeship was equally manifest in his devotion to "a new dimension, where ... the bounds of being disappear" than the joy and freedom of "a poem, settling to its form," "a norm ... of conduct, and a fitting sphere ... which stops it wandering everywhere" ( 10 ). He realizes: "Love's essence, like a poem's, shall spring / From the not saying everything" ( Room ). To him, Poems ( 1930 ) is one of the works of art which exemplifies the artistic, amoral identity of the poet and redefines "the boundary between" the passive and active poetry:

This tree outside my window here

Naked, umbrageous, fresh or sere,

Has neither chance nor will to be

Anything but a linden tree,

Even if its branches grew to span

The continent; for nature's plan

Insists that infinite extension

Shall create no new dimension.

From the first snuggling of the seed

In earth, a branchy form's decreed. (Room)

Day Lewis's comments in The Room underline the vastness and loftiness of Auden's structuralistic poetic justice:

Past selves are kept alive in it, a living

Communion flows from their dead languages. A home

Enlarged by absences, mellowed by custom,

Undemanding, simply taking and giving.

Poems ( 1930 ) sounds for Auden's genius in respect of its "infinite extension" and "single comprehension," “love's expression" and "purer ... limitation" "sweet illusion" and "the limits of what's human" according to Day Lewis.

In Overtures to Death, Day Lewis felt that he could achieve self-realization and play his proper role in society only by writing poetry but the thought of doing good to the world by dedicating himself to some more active service also occupied his mind. He expresses his fear and divided public conscience:
In the act of decision only,
In the hearts cleared for action like lovers naked
For love, this shadow vanishes
(DCP 188)

The idea of disinterestedness that he imbibed from Wilfred Owen and Warner found corrobation in Auden's example, "You and I with lilac lark and oak-leafed / Valley are bound together / As in the astounded clarity before death" ( $D C P$ ). Although Day Lewis was averse to popularity, he was acutely conscious of his obligation to society as soon as the Spanish War broke out:

It was not fraud or foolishness,

Glory, revenge, or pay:

We came because our open eyes

Could see no other way. (190) 
He volunteered for active service on the battle ground and he welcomed Auden's influence that led him to Spain for "the good" of community and the freedom of England.

Day Lewis's thoughts about life and poetry were invariably associated with Thomas during the pre-war years, and his Overtures to Death calls attention to the fact that in a number of his poems during this period there are echoes of Thomas's early works 18 Poems and 25 Poems. "Our thoughts like sailplanes go / To and fro sauntering / Along fantastic cloud-streets / On warmer currents' flow" ( 201 ). In his approach to Thomas Day Lewis was chiefly influenced by Yeats whose poem The Tower was the main impact on Transitional Poem, and many of Thomas's ideas are elaborations of Yeats's but while recognizing Thomas's debt to Yeats one should not ignore the individuality of his approach. Day Lewis evaluates:

$$
\begin{aligned}
& \text { Now, beyond reach of sense or reason, } \\
& \text { His life walks in a glacial sleep } \\
& \text { For ever, since he drank that cup } \\
& \text { And found it poison. } \\
& \text { He's one more ghost, engaged to keep } \\
& \text { Eternity's long hours and mewed } \\
& \text { Up in live flesh with no escape } \\
& \text { From solitude. (207) }
\end{aligned}
$$

Ideas for Thomas were never abstractions; he assimilated them in the sense that he realized them in concrete, sensuous practice in 18 Poems. Day Lewis remarks:

$$
\begin{aligned}
& \text { Freedom is more than a word, more than the base coinage } \\
& \text { Of statesmen, the tyrant's dishonoured cheque, or the dreamer's mad } \\
& \text { Inflated currency. She is mortal, we know, and made } \\
& \text { In the image of simple men who have no taste for carnage } \\
& \text { But sooner kill and are killed than see that image betrayed. } \\
& \text { Mortal she is, yet rising always refreshed from her ashes.... }(D C P)
\end{aligned}
$$

The poetic licence of Thomas's 18 Poems, "the time-bomb town," "the live rafters of the eardrum," "a parcel of stone," "the dark asylum" was for Day Lewis a commitment, and he sought to refashion his own mode of poetry in a spirit of dedication.

In Overtures to Death written after his painful experience in the symphony "A Time to Dance," as Day Lewis comes closer to Thomas, the distance between him and Auden becomes wider; and although the structuralistic sound patterns of Auden is not completely rejected, its relevance in the immediate historical phase is seriously questioned. Day Lewis notes a clearer understanding of Auden's historic structure of sorrow, "the skull of the earth is barbed with a war of burning brains and hair" and of his own position in relation to Thomas's process of alchemization of sorrow into joy, "the horrid ... woe drip from the dishrag hands and the pressed sponge of the forehead" as evidently manifested in the sonnets "Altarwise by Owl-Light," "the stocked heart is forced, and agony has another mouth to feed," and a firmer grasp of his own destination as a poet, "a thundering bullring of your silent and girl-circled island."

Spender, discarding the world of pure fantasy, the Shelleyan stunt, "vessel of abscesses and exultation's shell," the impersonal technique of the passionate, "furious" Warner, "the spelling wall ... the invoked, shrouding veil," adopts Auden's symbolic technique, his "wizard shape ... in the cavernous skull" of Poems ( 1930 ) to design the pressure of the horrible contemporary reality. The Audenesque ideal inspired emulation, but its dizzy heights were also forbidding. The distance precluded any real identification, and it is Spender's failure to establish any meaningful relationship with the austere intellectual poet that explains, at least partly, his subsequent repudiation of the relevance of the Audenesque model for himself. Indeed, Spender approached Auden with a divided heart; and his Poems ( 1933 ) witnesses his heroic efforts come close to the colossus and create art songs but leaves in no doubt about the wide gap between the two. Thomas comments in the poem "How Shall My Animal":

Sigh long, clay cold, lie shorn,

Cast high, stunned on gilled stone; sly scissors ground in frost

Clack through the thicket of strength, love hewn in pillars drops

With carved bird, saint, and suns the wrackspiked maiden mouth

Lops as a bush plumed with flames, the rant of the fierce eye,

Clips short the gesture of breath. (64) 
While Spender was drawn to Owen for genuine human concern, "a living skein ...tongue and ear in the thread, angle the temple-bound," the weight of Auden's intellect and musical art also staggered him. "Die in red feathers when the flying heaven's cut, / And roll with the knocked earth: / Lie dry, rest robbed, my beast." Assuming that the quantity of matter is fixed and that the total quantum of intelligence is limited, Thomas concludes that Auden absorbed as it were all resources of the mind and thus exhausted the possibilities of human intellection. "You have kicked from a dark den, leaped up the whinnying light, / And dug your grave in my breast." The statement is made light-heartedly, but the facetiousness of his tone does not conceal the inner dismay. Some of his comments as sketched in the second stanza of the poem underline the vastness and loftiness of Auden's conceptions of poetry from Poems ( 1928 ) to Another Time ( 1940 ) eversince he has pilgrimaged as a poet in pursuit of myth and reality. Auden's poetical genius, Thomas writes:

How shall it magnetize,

Towards the studded male in a bent, midnight blaze

That melts the lionhead's heel and horseshoe of the heart

A brute land in the cool top of the country days

To trot with a loud mate the haybeds of a mile,

Love and labour and kill

In quick, sweet, cruel light till the locked ground sprout

The black, burst sea rejoice,

The bowels turn turtle,

Claw of the crabbed veins squeeze from each red particle

The parched and raging voice? (Poems)

But it would be wrong to label Spender as a lonely sceptic, writes MacNeice:

O greyness run to flower,

Grey stone, grey water

And brick upon grey brick. (187)

Auden's was almost a sobering influence on the poetic personality of Spender. "No poet could have better chosen to expose Spender's deficiencies and undermine his self-confidence than W.H. Auden" ( Thurley 83 ). His patronizing gesture simply sharpened his sensibility but it could not suppress his essentially social conscience.The poetical character of Auden's poetry as imaged in Spender's Poems ( 1933 ) is identical to the verbal message of de la Mare in Motley and Other Poems ( 1918 ):

When music sounds, gone is the earth I know,

And all her lovely things even lovelier grow;

Her flowers in vision flame her forest trees

Lift burdened branches, stilled with ecstasies. (199)

This implies considerable departure from the structuralistic music of Auden, and Spender's approach is both a defence and a repudiation of his great contemporary, Auden.

\section{Findings and Interpretations}

Apparently, the poem "On no Work of Words" representing the locus classicus of Thomas's The Map of Love offers a comparative and contrastive assessment of the time-conscientious poets, Day Lewis, Spender, and MacNeice and the life-conscious War poets, Fuller, Rook, and Rhys. The issues involved are wider and cover the whole range of aesthetic transcendence and intensity of Auden. Thomas seeks to correlate the two apparently divergent areas of experience:

\section{Ancient woods of my blood, dash down to the nut of the seas}

If I take to burn or return this world which is each man's work. (Poems)

In the case of Day Lewis, Spender, and MacNeice, the knowledge of post-war climate, the transience of their poetry, the omnipresence of death, and equally the unending attendant pain chills their mind's responsiveness to Auden's cold beauty.Their pain is born of involvement, of gnawing self-consciousness associated intensity with horror. MacNeice, whose perceptive commentary enables the readers much to understand the difficult and remarkable passage of the poem "On No Work of Words" suggests that Auden's Poems contains an apprehension of an ultimate reality which is impersonal. He persuasively argues that Auden does not represent a mere impersonal order and stresses the Christian implications of the poems: "The boom of dawn that left her sleeping, showing / The flowers mirrored in the mahogany table" (MCP 109). There were other needs and aspirations, "conscience, need, imagination," equally compulsive ; and 
although the readers can note the choice of a particular norm at a particular phase, the inner struggle continued throughout. "The fabric of tears; but in truth / it is we, not time bleed" ( $D C P$ ). Day Lewis remembers:

We lament not one year only

Gone with its chance and change

Disavowed, its range of blessings unbought or unpaid for,

But all our time lost, profitless, misspent. $(D C P)$

The thesis of art-conscious Lefties, Day Lewis, Spender, and MacNeice regarding their acceptance and rejection of Auden has the neatness of a diagram. But the War poets's repudiation of Auden, "the ghost of time," "an age coarse custom has buried alive" like Prince's rejection of Thomas's "life-blood" miss the contrary direction of the poet's mind and art.

There is, however, an added realization in the Lefties that there is a higher mode of knowledge in Thomas's early poetry the attainment of which liberates their mind from pain and death. Thomas testifies:
And death shall have no dominion.
Dead mean naked they shall be one
With the man in the wind and the west moon;
When their bones are picked clean and the clean bones gone,
They shall have stars at elbow and foot.... (Poems)

Auden's contemporaries were struck by Thomas's self-effacement of the poet's personality, the impersonal, objective treatment of natural phenomena, and the serene, impassioned quality of 18 Poems. "Look, in what scarlet character they speak! / For this their russet and rejoicing week / Trees spend a year of sunsets on their pride" ( DCP 169 ). Day Lewis in Overtures to Death, especially in the sonnets "O Dreams O Destinations," Spender in The Still Centre, and MacNeice in The Earth Compels speak in a new voice; their poems demonstrate, if the grandeur of Auden is partly sacrificed, there is a distinct gain in economy and in directness. MacNeice admits:

\section{Our freedom as free lances \\ Advances towards its end; \\ The earth compels, upon it \\ Sonnets and birds descend; \\ And soon, my friend,}

We shall have no time for dances. (104)

Auden's contemporaries moved in a new direction - the accent strikes the observer refreshingly modern-but the transition remains uncompleted.

Thomas who had shown vicariousness to the afflictions of the poets of thirties in his early poetry extended the same to the dilemmatic War poets in his transitional poem. "The grave and my calm body are shut to your coming as stone, / And the endless beginning of prodigies suffers open" ( Poems ). His cynical concern, his unpity for the War poets has been his poetic character emenated from--"the singing workmen shape and set and join ... their frail new mansion's stuccoed cove and quoin" ( $H C P$ 90) and "old lecher with a love on every wind" ( $Y C P$ )-- the poetic tradition of Hardy and Yeats, his "nests of mercies in the rude, red tree" ( Poems ). In 18 Poems, he has shown "the pulse of summer in ice" towards the grievous poets of thirties, "the boys of summer in the ruin" ( 71 ) and in 25 Poems, he breaks "the bread"and enacts "the resurrection in the desert ... death from a bandage," "rivers of the dead around my neck" ( 38 ), the sonnets "Altarwise by Owl-Light" for his alteregos, Day Lewis, Spender, and MacNeice whose love for Auden's musicality led "to dusts and furies." In this regard, Thomas's paradoxical poetic licence, his "intricate image," his "man-iron sidle" ( 73 ), "the natural parallel," the language of paradox and co-existence stands as a sharp contrast to Auden's historic consciousness and grand manner "the long world's gentleman," his language of irony and dissociation.

Obviously, Thomas's early works and his transitional work vindicate the successful process of creativity and productivity, his poetics and his happiness. To Fuller, Rook, and Rhys, the poetic functioning of Thomas stands as a stark contrast to Auden's. They heaved a sigh of relief as the world-concentric Thomas's 18 Poems offers a hope for poetry, "life-blood" for their poetic mind fumbling around Auden's "foreign-looking luggage" and "the unheard-of constellations wheel" ( MCP 193 ), his historic consciousness involving "a perception" of "the whole of the literature of Europe from Homer and within it the whole of the literature of his own country" ("Tradition" 169). They perceived "like wavering antennae feel ... around the sliding limber towers of Wall Street ... into the hinterland of their own future ... behind this excessive annunciation towers"; while "tracking their future selves through a continent of strangeness," they moved like "the liner ...to the magnet" ( $M C P$ ). MacNeice points out the rationale underlying the War poets's choice of Thomas: 
With prune-dark eyes, thick lips, jostling each other

These, disinterred from Europe, throng the deck

To watch their hope heave up in steel and concrete

Powerful but delicate as a swan's neck.... ( $M C P)$

This explains why Thomas's de-idealized earth-concentric poetic tradition is deeper than Auden's ideological structuralistic tradition; Auden's Word-centric communicative functioning and the language of sounds can be learnt through study and intellectual effort, but Thomas's de-centred, ex-centric aesthetic functioning and the language of "red heart" demands a different kind of understanding - the reader must be able to experience his vision.

In The Map of Love, the poetic licence and vicariousness that Thomas arrives at is the fruit of prolonged "labours," the Yeatsian impersonality and enriched by his own experiences in life. "Sobriety is a jewel ... that I do much adore" ( YCP 268 ). It is, in a sense, an extension of Hardy's ideal of transfiguring mind, "serene, sacacious, free" ( HCP 75 ), "the lacking sense scene," "a sad-coloured landscape" that transmutes "distress into delights" because "self-smitings kill self-joys" ( 102 ). Thomas unveils:
In the groin of the natural doorway I crouched like a tailor
Sewing a shroud for a journey
By the light of the meat-eating sun. ( Poems )

In the poem "A Bronze Head" Yeats, while underscoring the Eliotian "profound" poetic justice, "the extreme of life and death," "all sleek and new," "the wildness," "a vision of terror that it must live through ... had shattered her soul," murmurs the mystery underlying his poetry right from the beginning of his poetic career: "Propinquity had brought / Imagination to that pitch where it casts out / All that is not itself" ( 289 ). And in the poem "The Dead Drummer Hodge," Hardy defines the meaning percipient and objective mind: "his landmark is a kopje-crest ... that breaks the veldt around" ( 80 ).

\section{Conclusion}

The ideals of poetic empathy and poetic licence evolved in The Map of Love are, therefore, central to an understanding of Thomas's entire poetic ouvre, more particularly, of the maturer poetry of the later phase carving out a road taken already to immortality, "Gay forms, that cross and whirl and wind ... to music throbbing through..." ( HCP 159 ).The poem "marks the beginning of that deepening and extension of poetic sympathy and personal vision that characterizes Thomas's later work" ( Ackerman 73 ). What Thomas sums up in the poems of The Map of Love, on the whole, is that the modernistic and stylistic structure of Auden's early works, while insisting upon "that the poet must develop or procure the consciousness of the past and that he should continue to develop this consciousness throughout his career" ( "Tradition" ), justifies the necessity to restore the transcendental structures of power and ideologies for freedom. In contradistinction to Auden, the archetypal "stylite" of Thomas's transitional poem has been forwarding in the same direction of poetic licence and spirit of his early poetry, "he turned his head but to glimpse the ghost of her" ( DCP 267 ), and emerging as an image of individual potential and freedom to advance his poetic functioning and poetic language, his "poetics" in anticipation of the functioning of his poetic character and poetic culture in the next volume Deaths and Entrances. "There is nothing left of the sea but its sound, / Under the earth the loud sea walks... ( Poems 38 ). Auden, in Another Time, expressing his doubt about the validity of the notion of continual progress and the thought that the finality of death made all progress illusory increasingly engrossed his mind, moves "to further griefs and greater ... and the defeat of grief" ( 16 ). His eclectic, ironic art tries "to prove ... humanism a palimpsest and God's ... anger a more primal fact than love" ( MCP 198 ) while the readers can witness his anxious search for the meaning of sorrow and salvation, culture and anarchy, mortality and immortality in the absurd world of meaninglessness and freeplay. But Thomas's concern in Deaths and Entrances as a poet continues to be the exploration of the inner reality, "a bird's sleepy cry ....among the deepening shades" ( YCP 168 ). MacNeice makes a comparative estimate of Auden and Thomas:

The luck and pluck and plunge of blood,

The wealth and spilth and sport of breath,

And sleep come down like death above

The fever and the peace of love.... (191)

For Thomas poetic practice is integrated with the practice of living. He surveys the map of his poetic tradition and his poetic functioning past and present while forgetting everything about the future and the immortality of his poetry:

Dressed to die, the sensual strut begun,

With my red veins full of money,

In the final direction of the elementary town

I advance for as long as forever is. (Poems 140) 
The system of salvation that Thomas offers in Deaths and Entrances is the elaboration of the poetic vision of his 18 Poems, the emulation of aesthetic ideal into a way of life which whispers the "lament" of Hardy's Tess: "I cannot bear my fate as writ, / I'd have my life unbe..." ( Hardy 158 ) and remembers "men that made a man of me" ( Houseman 9 ). Thomas's poetic functioning has been a search for a coherent system that would explain the tragic mystery of life and offer a mode of release for co-existence. "And blended pulsing life with lives long done, / Till Time seemed fiction, Past and Present one" (89).

\section{References}

Ackerman, John. Dylan Thomas: His Life and Work. London: Macmillan, 1964. Print.

Auden, W.H. Poems. London: Faber, 1930. Print.

---. The English Auden:Poems.Essays and Dramatic Writings 1927-1939. Mendelson, Ed. London: Faber, 1977. Print.

---. Another Time. London: Faber, 1940. Print.

Bloom, Harold. "Poetic Origins and the Final Phases." David Lodge, Ed. Modern Criticism and Theory: A Reader. New Delhi: Pearson, 1998. Print.

Davies, Walford. Dylan Thomas .New Delhi: Viva Books, 2003. Print.

Day Lewis, Cecil. Collected Poems 1929-1954. London: Hogarth-Cape, 1954. Print.

---. The Room and the Other Poems. London: Jonathan Cape, 1965. Print.

De la Mare, Walter. The Complete Poems. London: Faber, 1969. Print.

Eliot,T. S. "Tradition and the Individual Talent." S. Ramaswami and V.S. Sethuraman, Eds. The English Critical Tradition: An Anthology of English Literary Criticism Vol.2 Madras: Macmillan,1978. Print.

---. "Hamlet and His Problems." The Sacred Wood: Essays on Poetry and Criticism. London: Methuen, 1960. Print.

Hardy, Thomas. Collected Poems. Herfordshire: Wordsworth, 2006. Print.

Jakobson, Roman. "Poetics and Linguistics." David Lodge, Ed. Modern Criticism and Theory: A Reader. New Delhi: Pearson, 1998. Print.

MacNeice, Louis. Collected Poems 1925-1948. London: Faber, 1949. Print.

Houseman, A.E. Poems. London: Hunter, 2004. Print.

Shires, M.Linda. British Poetry of the Second World War. London: Macmillan, 1985. Print.

Spender, Stephen. Nine Experiments. Hampstead: Frongal, 1928. Print.

Thomas, Dylan. Poems. London: Hunter, 2004. Print.

Thurley, Geoffrey. The Ironic Havest: English Poetry in the Twentieth Century. London: Edward Arnold, 1974. Print.

Wordsworth, William. "Preface to the Lyrical Ballads." D.J. Enright and Ernest de Chickera. Eds. English Critical Texts: 16 th Century to 20 th Century. London: Oxford UP, 1962. Print.

Yeats.W.B. Collected Poems. London: Wordsworth, 2004. Print. 